\title{
Expression of the rice hoja blanca virus (RHBV) non-structural protein 3 (NS3) in Escherichia coli and its in situ localization in RHBV-infected rice tissues
}

\author{
Miguel Muñoz ${ }^{1}$, Isela Bolaños ${ }^{1}$, Griselda Arrieta-Espinoza ${ }^{1}$ \& Ana M. Espinoza ${ }^{1,2}$ \\ 1 Centro de Investigación en Biología Celular y Molecular (CIBCM), Universidad de Costa Rica. \\ 2 Escuela de Agronomía, Facultad de Ciencias Agroalimentarias, Universidad de Costa Rica.
}

Received 20-VIII-2002. Corrected 09-VI-2003. Accepted 30-VII-2003.

\begin{abstract}
The non-structural NS3 protein gene from the rice hoja blanca virus (RHBV) was fused to the glutathione-S-transferase carboxilic end and expressed in Escherichia coli strain JM83. Large quantities of fusion protein were produced in insoluble form. The fusion protein was fractionated in SDS-PAGE and purified by electroelution, polyclonal antibodies were raised in rabbit and the antiserum was absorbed with bacterial crude extract. A band of similar size as that of NS3 protein was observed in Western blots using extracts from RHBVinfected rice plants. Immunoelectron microscopy with colloidal gold-labeled antibodies against NS3 protein and the viral nucleocapsid protein revealed in situ accumulation of NS3 protein in the cytoplasm but not in the viral inclusion bodies, vacuoles or chloroplasts of RHBV-infected plants, following the same pattern of distribution as the RHBV nucleocapsid protein. Rev. Biol. Trop. 52(3): 765-775. Epub 2004 Dic 15.
\end{abstract}

Key words: Rice hoja blanca virus, RHBV, NS3, polyclonal antibodies, immunoelectron microscopy.

Palabras clave: Virus hoja blanca, arroz, RHBV, NS3, anticuerpos policlonales, inmunoelectro microscopía.

Rice hoja blanca is a viral disease that occurs in cyclical outbreaks, reaching epidemic levels maintained over several years. It is currently affecting rice production in Tropical America and the Caribbean. Hoja blanca disease is caused by a planthopper-transmitted virus: the rice hoja blanca virus (RHBV, Tenuivirus), which induces chlorotic stripes, systemic chlorosis and seed sterility in cultivated rice plants (Jennings 1963). The virus is persistent and propagative in the delphacid insect vector (Tagosodes orizicolus, Homoptera: Delphacidae), which in turn is able to transmit the virus transovarially to the progeny (Nault and Ammar 1989).

RHBV is a non-enveloped multipartite RNA virus, it has an $18 \mathrm{~Kb}$-genome arranged in four negative sense and ambisense genomic
RNAs of different sizes, totaling seven open reading frames (ORFs) (Ramírez and Haenni 1994). Sequence analysis of RHBV RNAs has revealed a viral RNA polymerase ORF in RNA-1 similar to rice stripe virus RNA polymerase (Toriyama et al. 1994, Muñoz et $a l$., unpublished results). Two ORFs encoding putative membrane-glycoproteins of unknown function are found in the ambisense RNA-2 (de Miranda et al. 1995, 1996). The ambisense RNA-3 encodes the viral nucleocapsid protein $(\mathrm{N})$ and a nonstructural protein (NS3) of unknown function (de Miranda et al. 1994). The ORFs for the inclusion bodies protein and another non-structural protein (NS4), of unknown function are located in the ambisense RNA4 (Ramírez et al. 1993). 
Genomic RNA-3 and RNA-4 are the most abundant RNAs in RHBV-infected tissues, however, only two genes have been asigned to known proteins: N-protein, found associated with ribonucleoproteins (RNP), and the noncapsid protein (NCP), found in cytoplasmic inclusion bodies. Sequence analysis has revealed short stretches of aminoacids in NS4 similar to those found in potyviral insect transmission factors (Ramírez and Haenni 1994). The function of the $n s 3$ gene is still unknown, DNA database searches using $n s 3$ sequence from different tenuiviruses has not revealed homology sequence so far (Huiet et al. 1991, Kakutani et al. 1991, de Miranda et al. 1994). It has been suggested that it may encode the viral movement protein (Ramírez and Haenni 1994).

Infectious clones of RHBV or mutant versions of the $n s 3$ gene are not yet available for functional analysis, however, it may be possible to study the subcellular localization of NS3 protein using specific antibodies and derive a model for further study. This strategy requires the purification of the viral proteins and the production of polyclonal antibodies. The viral gene can be subcloned in bacterial expression vector systems, by insertion at the 3' end of a gene that encodes a highly expressed transporter protein (Smith and Corcoran 1992), producing a chimeric fusion protein (Marston 1987). One of such expression vectors is the pGEX plasmid family, the polypeptide of interest is fused to the carboxilic end of the 26 $\mathrm{kDa}$ glutathione-S-transferase (GST) from Schistosoma mansoni (Smith et al. 1986). These vectors contain the IPTG-inducible tac promoter (Amann et al. 1983), and the GST open reading frame (ORF) (Smith et al. 1986), in which the termination codon is replaced by a multiple cloning site followed by the termination codon TGA. Protein expression is induced with isopropyl thio-b-D-galactoside (IPTG), allowing the purification of the fusion protein from crude bacterial lysates under nondenaturing conditions by glutathione affinity chromatography (Smith and Cocoran 1992).

To determine in situ localization of the NS3 protein in RHBV-infected plants, the
NS3-GST fusion protein was expressed in $E$. coli, purified and used for the production of polyclonal antibodies. Immunological tests revealed the expression of the NS3 protein in extracts of infected plants; gold-labeled antibodies localized the protein in the cytoplasm along with the viral nucleocapsid.

\section{MATERIALS AND METHODS}

Cloning and expression of the RHBV $n s 3$ gene in $\boldsymbol{E}$. coli: The $n s 3$ gene was amplified by PCR from a RHBV cDNA-3 fulllength clone (Genebank L07940) previously sequenced from a viral genomic library (de Miranda et al. 1994). A $0.61 \mathrm{~Kb}$ fragment containing the full ORF was recovered using two specific primers. NS3-Forward primer (5'-

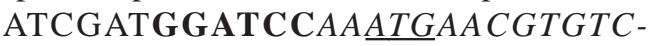
CTTTTGAA-3') includes the 5' end of the ORF, (bases 96 to 115, in italics), the BamHI restriction site (bold) and the initiation codon (underlined). The NS3-Reverse primer (5'-

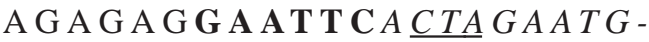
GAAGCAGTAA-3') contains the 3' of the ORF (bases 717 to 734, in italics), the EcoR1 restriction site (bold) and the termination codon (bold italics) (Fig. 1). Ten nanograms (ng) of plasmid template were amplified by PCR in a mixture containing $20 \mathrm{mM}$ Tris- $\mathrm{HCl}$ $\mathrm{pH} 7.8,40 \mathrm{mM} \mathrm{KCl}, 1.5 \mathrm{mM} \mathrm{MgCl}_{2}, 0.1 \%$ BSA, $0.2 \mathrm{mM}$ dNTPs, $0.4 \quad \mathrm{M}$ each primer and 2.5 units of Taq polymerase. The PCR thermal profile was two cycles of $94^{\circ} \mathrm{C}$ for $60 \mathrm{~s}, 45^{\circ} \mathrm{C}$ for $30 \mathrm{~s}$ and $72^{\circ} \mathrm{C}$ for $2 \mathrm{~min}$, followed by 32 cycles of $94^{\circ} \mathrm{C}$ for $60 \mathrm{~s}, 55^{\circ} \mathrm{C}$ for $30 \mathrm{~s}$ and $72^{\circ} \mathrm{C}$ for $2 \mathrm{~min}$. The PCR product was digested with BamHI and EcoRI enzymes and inserted inframe at the 3'end of the GST gene in the pGEX3X expression vector, to make plasmid pGST-NS3. The insertion site is located downstream the factor Xa protease recognition site (Ile-GLu-Arg) for cleavage of the protein from the fusion product. Heat-shock competent $E$. coli cells, strain JM83, were transformed with pGST-NS3 and pGX3X vector. Bacterial cultures were grown for two hours in $50 \mathrm{ml}$ liquid 


\section{Factor Xa \\ Ile Glu Gly Arg BamHI Start EeoRI Stop \\ ATC GAA GGT CGT GGG ATC CAA ATG [NS3 ORF] GGAA TTCA TCG TGA CTG}

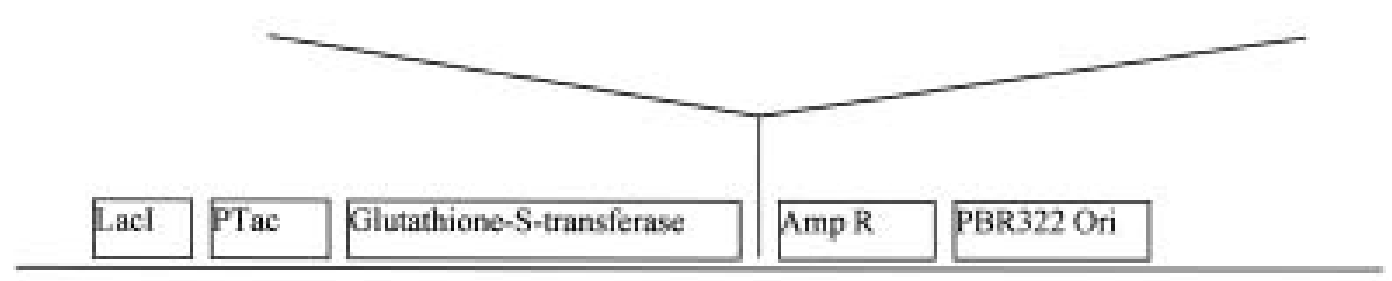

\section{pGST-NS3 (5.5 kb)}

Fig.1. Plasmid pGST-NS3 for expression of GST-NS3 fusioN-protein in E. coli.

LB broth, then IPTG $(0.1 \mathrm{mM})$ was added and the culture was incubated for six hours at $37^{\circ} \mathrm{C}$. Induced cells were separated by centrifugation $10000 \mathrm{rpm}$ for $5 \mathrm{~min}$ and re-suspended in $10 \mathrm{ml}$ saline phosphate buffer 1X PBS. Cells were lyzed using three different methods: thermal shock by freezing at $-70^{\circ} \mathrm{C}$ for $15 \mathrm{~min}$ and thawing at $37^{\circ} \mathrm{C}$ for $20 \mathrm{~min}$ (four cycles), enzymatic digestion with lysozyme $(120 \mathrm{mM})$ or four pulses of sonication for $30 \mathrm{~s}$ (Virsonic 50, Virtis, USA). The lysate was centrifuged $10000 \mathrm{rpm}$ for $5 \mathrm{~min}$ at $4^{\circ} \mathrm{C}$, the supernatant was transferred to a separate tube and the pellet was re-suspended in $1 \mathrm{X}$ PBS, $1 \%$ Triton X-100 (SIGMA $\left.{ }^{\circledR}\right), 50 \mathrm{mM}$ EDTA, 1 mM PMSF (phenylmethylsulfonylfluoride), and $10 \mathrm{mM}$ DTT (dithiothreitol). The supernatant and pellet were fractionated in $12 \%$ SDS-PAGE (Laemmli 1970). Since the fusion protein was mainly insoluble, glutathione affinity chromatography columns were clogged and little protein was recovered. When solubilized protein was fractionated, co-purification of large quantities of other bacterial protein was recovered. Therefore, crude extracts were fractionated in $12 \%$ SDS-PAGE preparative gel and stained in $0.1 \%$ Coomassie blue. The fusion protein band was cut out and electroeluted for two hours at $200 \mathrm{~mA}$ in Tris-Glycine buffer (25 mM Trisbase, $250 \mathrm{mM}$ glycine and $0.1 \%$ SDS), using an electroelution chamber (BioRad"). The purified fusion protein was dialyzed with $1 \mathrm{X}$ SSC and analyzed in SDS-PAGE gels to estimate protein concentration.
Preparation of polyclonal antibodies against the GST-NS3 fusion protein: Polyclonal antibodies directed against the GST-NS3 fusion protein were produced in rabbits by injection into the hind foot with an emulsion of $0.5 \mathrm{ml}$ Freund's complete adjuvant and $0.5 \mathrm{ml}$ of purified protein (approximately $1.66 \mathrm{mg} / \mathrm{ml}$ ) or bacterial crude extract containing the GST-NS3 fusion protein. Two weeks later a similar amount of antigen plus Freund's incomplete adjuvant was injected, another four booster inoculations were injected, once every 2 weeks. Rabbits were bled from the ear 12 days after the last inoculation, blood was collected and incubated two hours at $37^{\circ} \mathrm{C}$, then incubated at $4^{\circ} \mathrm{C}$ overnight and the antiserum was separated by centrifugation at $3000 \mathrm{~g}$ for $30 \mathrm{~min}$. The antiserum was evaluated by double immunodiffusion test in agar and in Western blots. Immunodiffusion was done in $0.3 \%$ agar plates, diluting two-fold the antigen and antiserum, followed by incubation for 24 to 48 hours in a moist chamber.

Western blot analysis: Western blot assays were carried out as indicated in Sambrook et al. (1989). Crude extract of $E$. coli and rice plants, as well as RHBV-infected plants and RHBV proteins (22 kDa NCP and $34 \mathrm{kDa} \mathrm{N}$-protein) were used as controls. Leaf tissue $(0.2 \mathrm{~g})$ was homogenized in liquid nitrogen and mixed with $1 \mathrm{ml}$ of sample buffer for protein electrophoresis $(0,065 \mathrm{M}$ Tris- $\mathrm{HCl} \mathrm{pH}$ $6.8,2 \%$ SDS, $40 \%$ glycerol, 5\% mercaptoethanol and $0,001 \%$ bromophenol blue) 
supplemented with $50 \mathrm{mM}$ EDTA, $10 \mathrm{mM}$ DTT and $1 \mathrm{mM}$ PMSF. The membrane was incubated first with the antiserum against crude or the purified extract (1/1000 dilution), and then with alkaline phosphatase-labeled anti-rabbit IgG (1/500 dilution) (SIGMA). Nitroblue tetrazolium (NBT) and 5-bromo-4chloro-3-indolyl phosphate (BCIP) were used as substrates. Antiserum against purified extract was further purified by absorption with $10 \mathrm{mg}$ of freeze-dried crude extract from $E$. coli expressing the pGX3X without the $n s 3$ gene and incubated for two hours at $37^{\circ} \mathrm{C}$. The IgG fraction was purified through affinity chromatography. Staphylococcus Protein ASepharaised CL-4B column (Pharmacia ${ }^{\circledR}$ ) was washed with glycine buffer $(0.2 \mathrm{M}$ glycine- $\mathrm{HCl}$ and $0.5 \mathrm{M} \mathrm{NaCl}, \mathrm{pH} 2.8$ ) then it was equilibrated with Trizma Base buffer (0.05 M Trizma Base and $0.5 \mathrm{M} \mathrm{NaCl}, \mathrm{pH} 7.5$ ). Samples of $3 \mathrm{ml}$ were added to the column and filtered for 45 minutes. The column was washed with Trizma Base buffer and the flow-through was discarded, the IgG fraction was eluted with Glycine buffer and samples were collected and neutralized to $\mathrm{pH} 7$ with Trizma Base $\mathrm{pH}$ 8.8. The column was washed with Trizma Base buffer $\mathrm{pH}$ 7.5 and the samples were dialyzed with PBS 1X. Protein concentration was estimated by spectrophotometry at $280 \mathrm{~nm}$.

Immunogold labeling of ultrathin sections of infected leaves. Leaf tissues from healthy and infected plants were fixed in $2.5 \%$ glutaraldehyde in $0.05 \mathrm{M}$ sodium cacodylate- $\mathrm{HCl}$, $\mathrm{pH} 7.2$ for $16 \mathrm{hr}$ at room temperature. The samples were dehydrated in a series of ethanol solutions (30-100\%) for $20 \mathrm{~min}$ at room temperature. Propylene oxide was gradually substituted for ethanol $(3: 1,2: 2,1: 3$, and two changes of $100 \%$ propylene oxide). Infiltration was done with Spurr resin in several steps (3:1, $2: 2,1: 3$, and two changes of $100 \%$ resin) one hour per step. Polymerization carried out at $60^{\circ} \mathrm{C}$ for $24 \mathrm{hr}$. Samples were sectioned in an ultramicrotome LKB 8800 and the resin was removed by incubation in a saturated solution of sodium metaperiodate for $10 \mathrm{~min}$ in the dark and then washing with distilled water three times for five minutes in the dark. Nickel grids (200 mesh) were placed onto a droplet of a 1:50 dilution of rabbit anti-NS3 antibody and 1:250 dilution of mouse anti-N-protein antibody in blocking buffer (200 mM Tris- $\mathrm{HCl} \mathrm{pH}$ $7.4,1 \%$ BSA, $0.1 \%$ gelatin and $1 \%$ Tween 20 ) for $8 \mathrm{hr}$ at $4^{\circ} \mathrm{C}$ and then washed for $1 \mathrm{~min}$ in blocking solution. Grids were placed onto a droplet containing gold-labeled antibodies (AuroProbe EM GAR G10, Janssen, and diluted 1:20 in blocking buffer) for $2 \mathrm{hr}$ at room temperature. A double labeling was done using a mixture of anti-mouse IgG and protein Acolloidal gold of three diameters (10 and 20 $\mathrm{nm}$ anti-rabbit and $5 \mathrm{~nm}$ anti-mouse). Two antisera were used: mouse anti-N-protein, diluted 1:250, and rabbit anti-NS3, diluted 1:50. The sections were then stained with $4 \%$ uranyl acetate for $15 \mathrm{~min}$, rinsed with distilled water and then stained with lead citrate for 15 min. The preparations were examined using a Hitachi 7000 electron microscope.

\section{RESULTS}

Expression induction and analysis of the GST-NS3 fusion protein: Accumulation of a $49 \mathrm{kDa}$ protein was observed upon induction with IPTG in E. coli cultures containing plasmid pGST-NS3. A $49 \mathrm{kDa}$ protein is expected for a fusion derived from the $26 \mathrm{kDa}$ GST and $23.2 \mathrm{kDa}$ NS3 protein. Non-induced control sample did not accumulate the GSTNS3 fusion protein at all. The GST-NS3 fusion protein was found not to be toxic in E. coli, since post-induction periods as long as $6.5 \mathrm{hrs}$ at $37^{\circ} \mathrm{C}$ were tested without significant decrease in protein accumulation. Little degradation was observed in SDS-PAGE, indicating that the fusion protein is stable when expressed in $E$. coli (data not shown), however, protein additives were added to the lysis buffer: a serine protease-inhibitor (PMSF), a chelating agent (EDTA) and antioxidant (DTT) to increase protein stability. Furthermore, a nonionic surfactant (1\% Triton X-100) was added to diminish the association of the fusion 
protein to other bacterial proteins (Smith and Corcoran 1992). Cells were lysed enzymatically (lysozyme) or mechanically (sonication and multiple freeze-thawing cycles). Disruption of bacterial cells by sonication was the most efficient and reproducible method of protein extraction, total cell lysis was achieved with no protein degradation (data not shown).

Upon cell disruption, both the supernatant and the insoluble fraction were analyzed in $12 \%$ SDS-PAGE. The GST-NS3 fusion protein was always found in the insoluble pellet along with bacterial proteins (data not shown), addition of solubilizing agents such as Triton X100 increased its solubility; however other bacterial proteins were also observed in the supernatant along with the GST-NS3 fusion protein. Although pGEX vectors allow the protein of interest to be purified under non-denaturizing conditions through affinity chromatography
(Smith and Corcoran 1992), the eluted fusion protein was highly contaminated with other bacterial proteins that were bound to the column in a non-specific way. Thus, the fusion protein was purified under denaturing conditions using SDS-PAGE and electroelution, as suggested by Marston (1986).

Serological analysis of the GST-NS3 fusion protein: Rabbit antiserum produced against crude extract from transformed E. coli and against the purified fusion protein were able to detect denatured GST-NS3 proteins in Western blots, even at antisera dilutions of 1/1000 (Fig. 2 a and b). Although we expected the antisera raised against the purified extract to have higher specificity than that of crude extract, the GST-NS3 polyclonal antibodies also reacted non-especifically against a large collection of E. coli proteins (Fig. 2a, lanes 1 through 3). However, both GST and GST-NS3
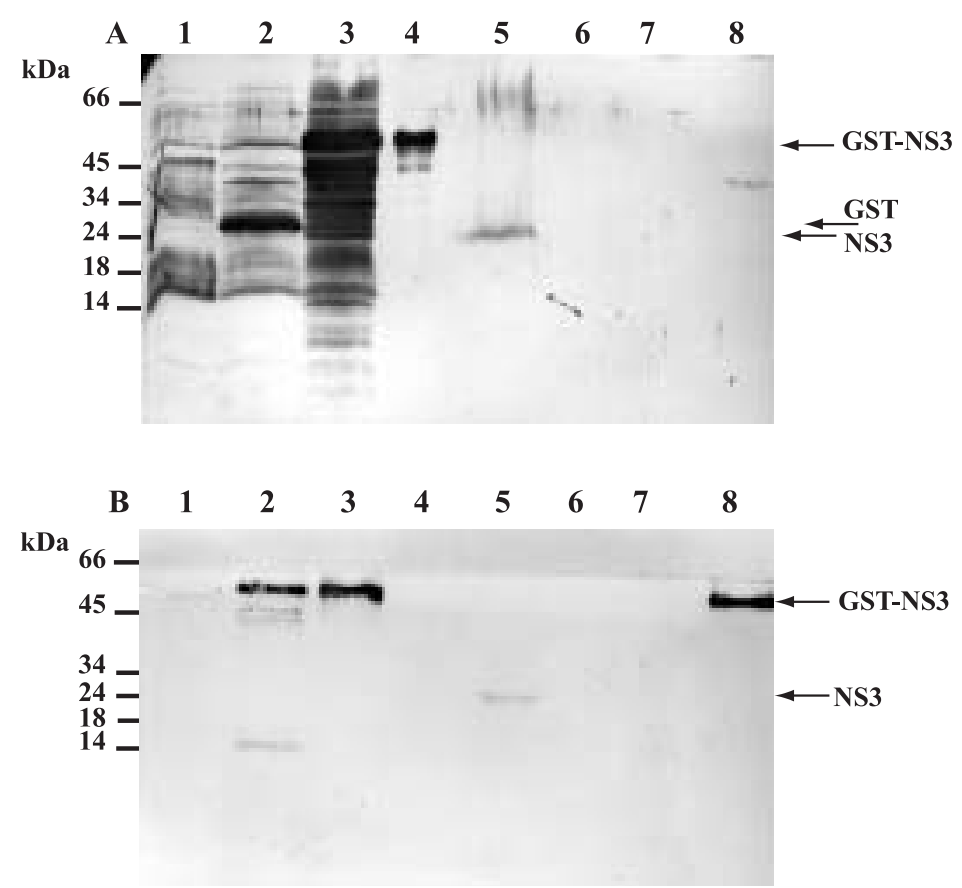

Fig. 2. Western blot analysis of crude (A) and adsorbed (B) polyclonal antibodies raised against GST-NS3 fusioN-protein. A. Non-adsorbed polyclonal antibodies. Non-transformed E. coli (lane 1), crude extract from a clone expressing GST (lane 2) and GST-NS3 fusion protein (lane 3), purified GST-NS3 fusion (lane 4), extract from RHBV-infected (lane 5), and healthy leaf tissue (lane 6), purified RHBV-NCP (lane 7), purified RHBV-N-protein (lane 8). B. Adsorbed polyclonal antibodies, crude extract from a clone expressing GST (lane 1), crude extract from a clone expressing GST-NS3 fusion protein (lane 2), purified GST-NS3 (lanes 3 and 8), extract from healthy rice (lane 4) and RHBV-infected leaf tissue (lane 5), NCP protein (lane 6), N-protein (lane 7). Arrows indicate GST, NS3 and GST-NS3. 
were clearly recognized by the antisera (lane 2 and 3, respectively). Since Mycobacterium was included in the adjuvant mixture for immunization, the antibodies raised may have cross-reacted with conserved proteins or epitopes in both E. coli and Mycobacterium. Plant proteins were not detected (lane 6), while RHBV-infected plants showed a single band of $23 \mathrm{kDa}$ (lane 5), as expected for the NS3 protein. Other viral protein, such as the NCP (lane 7), were not recognized by the antisera, however, a non-especific reaction was observed with the purified viral ribonucleoproteins (lane 8), although the band was slightly larger than expected for the $\mathrm{N}$-protein $(34 \mathrm{kDa})$.

Antiserum specificity was increased by adsorption of antibodies with lyophilized crude extracts from E. coli expressing GST (Fig. 2b). This procedure reduced non-specific binding with proteins other than GST-NS3 in bacteria (compare lanes 1 and 2), whereas both the GST-NS3 and RHBV-NS3 were detected in crude extracts from induced-E. coli cultures containing pGST-NS3 (lane 2), purified fusion protein (lanes 3 and 8) and extract from RHBV-infected leaves (lane 5). Furthermore, no signal was observed in extracts from healthy rice plants (lane 6), neither from viral proteins $\mathrm{N}$ and NCP (lanes 6 and 7 respective1y). The molecular weight of GST and NS3 proteins are similar (26 and $23 \mathrm{Kda}$, respectively), however, no signal was observed when extracts of $E$. coli expressing GST alone were analyzed by Western blot (Fig 2b. lane 1). This indicates that the adsorption procedure was efficient in precipitating non-specific antibodies, including those against GST, and that antibodies against NS3 do not cross react with epitopes from GST.

Immuno-localization of NS3 protein in RHBV-infected rice tissues: Polyclonal NS3 antibodies were purified and the IgG fraction was labeled with colloidal gold (20 nm and 10 $\mathrm{nm}$ gold particles); healthy and RHBV-infected rice leaves were analyzed in combination with mouse anti-viral ribonucleoprotein $(\mathrm{N}$ protein) antibodies labeled with $5 \mathrm{~nm}$ colloidal gold. While no signal was observed in mesophyll cells of healthy plants (data not shown), the antibodies mixture localized both NS3 and N-protein in infected cells (Fig. 3a and $3 b$ ). Both proteins were found in the same subcellular locations: mainly in the cytoplasm (Ct) and collapsing vacuoles (Fig. 3a). The antibodies could not detect either $\mathrm{N}$-protein or NS3 in chloroplast $(\mathrm{Cp})$, cell walls $(\mathrm{Cw})$, vacuoles (V) or inclusion bodies (IB) (Figs. 3a and $3 \mathrm{~b}$ ). Gold-labeled N-protein-antibodies were more abundant than NS3 labeled antibodies (Fig. 3c), a pattern that is more clear when larger gold particles were used $(20 \mathrm{~nm}$, Fig. 2d). The pattern of accumulation of labeled antibodies against NS3 and N-protein resembled that of the viral nucleocapsid protein in mesophyll cells, as previously described by Espinoza et al. (1993).

Cells from infected tissue showed collapsed vacuoles and a network of loosely attached fibrilar structures that extend towards the space left by the vacuole (Fig. 4a). Interestingly, antibodies raised against both NS3 and N-protein were also found associated to thin fibers (Fig. 4b and 4c), especially in collapsing cells that has already accumulated large masses of viral inclusion bodies. Although the fibrilar network was no evenly coated with labeled antibodies, most of the fibers were coated with both NS3 and N-protein antibodies (Fig. 4c). N-protein antibodies were observed at higher frequency as compared to those of NS3 (Fig. 4c and 4d). These structures were also observed in the cytoplasm.

\section{DISCUSION}

The function of viral proteins can be studied using different approaches including mutagenesis and complementation with wild type genes, ectopic expression of wild type proteins in transgenic plants or chimeric proteins containing reporter peptides, such as fluorescent domains. However, because of the lack of infectious clones and the requirement of planthopper vectors for virus transmission, mutagenesis experiments have not been carried out 


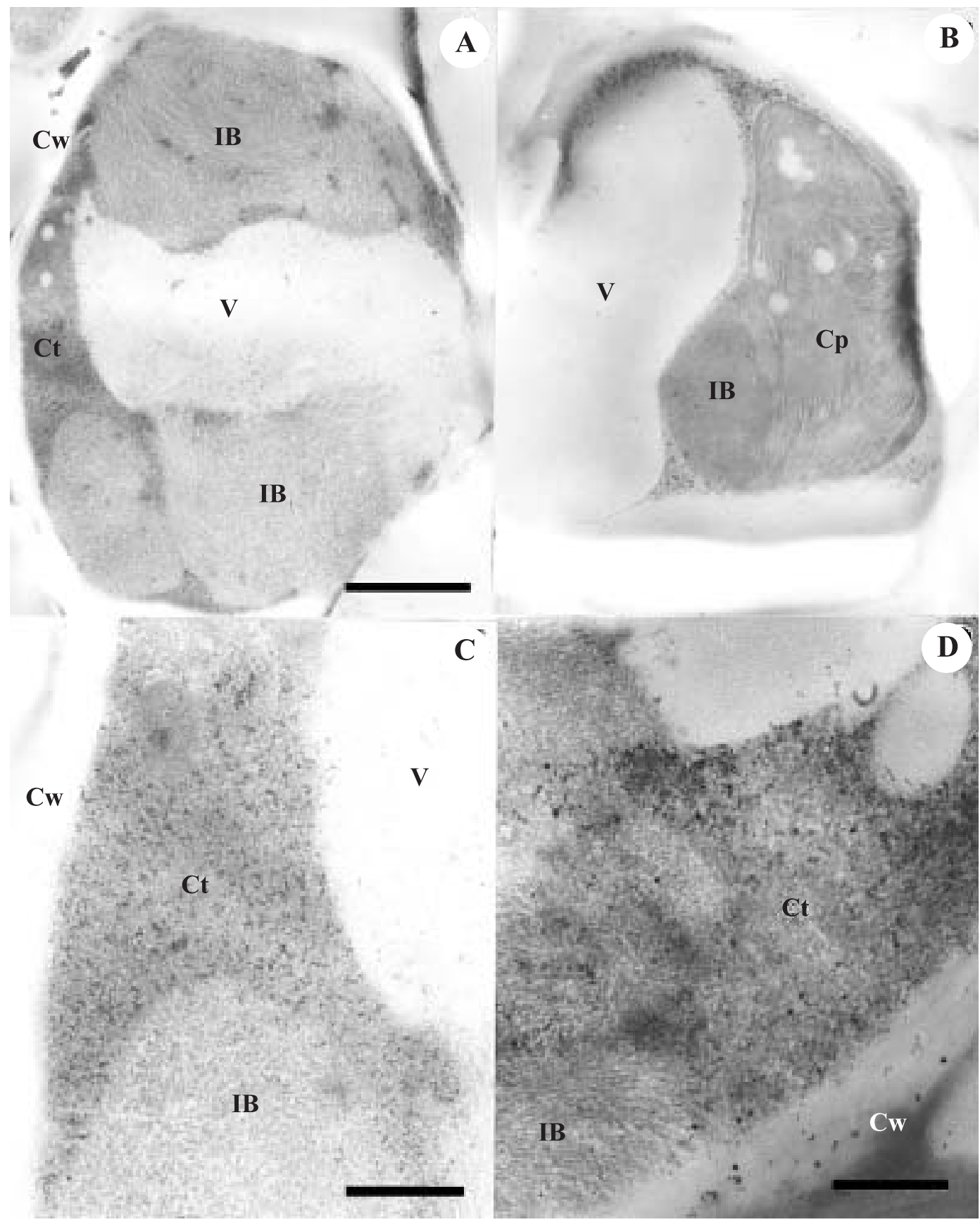

Fig. 3. Transmission electron micrograph of cross sections from RHBV-infected rice leaves immunogold-labeled with rabbit anti-RHBV-NS3 (10 nm and $20 \mathrm{~nm}$ gold particles) and mouse anti-N-protein antisera (5 nm). A and B. NS3 and N-protein co-localizing in the cytoplasm $(\mathrm{Ct})$ and very thin fibrillar network but not in viral inclusion bodies (IB) neither in vacuoles $(\mathrm{V})$, chloroplast $(\mathrm{Cp})$ or cell walls $(\mathrm{Cw})(\mathrm{A}$, bar=1.6 $\mathrm{m}, \mathrm{B}$, bar $=0.75 \mathrm{~m})$. C and D. Cytoplasmic co-localization of gold-labeled antisera with $10 \mathrm{~nm}$ (C) and $20 \mathrm{~nm}$ (D) NS3 gold-labeled antibodies (bar: $0.23 \mathrm{~m}$ ). 


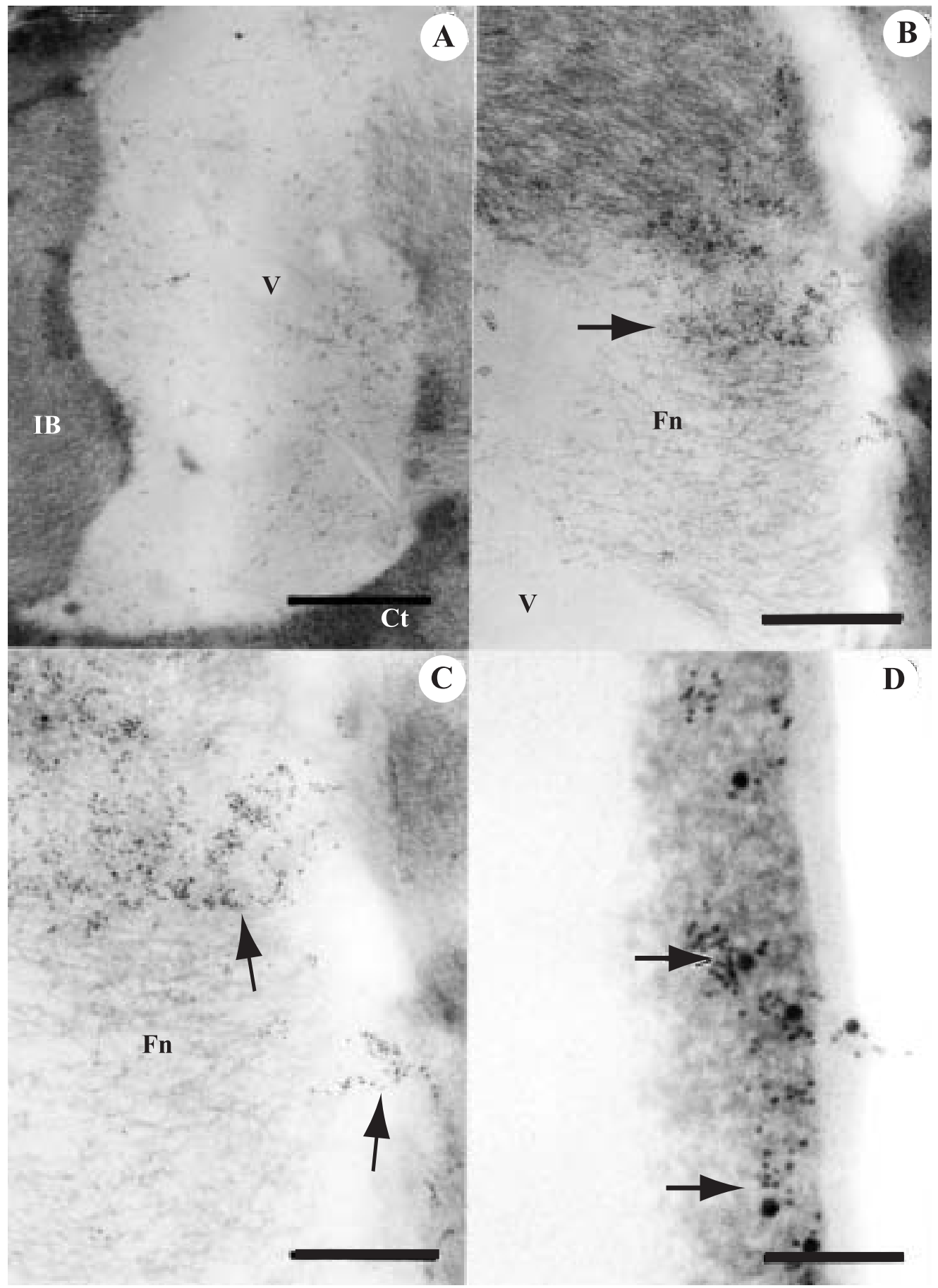

Fig. 4. Transmission electron micrograph of cross sections from RHBV-infected rice leaf tissue cells (A and B). Immunogold-labeling of RHBV NS3 and N-protein. Intense labeling occurs in fibers invading a collapsed vacuole but not in inclusion bodies ( $\mathrm{A}$ and $\mathrm{B}$, bar= $=.12 \mathrm{~m}$ ). $\mathrm{C}$ and $\mathrm{D}$ : detail of the cytoplasm showing co-localization of $5 \mathrm{~nm} \mathrm{~N}$-protein and NS3 gold-labeled antibodies of $10 \mathrm{~nm}(\mathrm{C}$, bar=0.25 m) or $20 \mathrm{~nm}(\mathrm{D}$, bar=0.2 $\mathrm{m}) \mathrm{NS} 3$ gold-labeled antibodies in fibers (Fn), in fibrilar structures, indicated by arrows. 
with tenuiviruses. Moreover, the requirement of full-cDNAs, in vitro transcription of each one of the genomic RNAs and mix-and-match of each component along with the viral replicase makes this sort of experiments technically very difficult to perform.

An alternative approach is the expression and purification of viral genes as fusion proteins expressed in bacteria and the production of antiserum for immunological studies. However, when recombinant proteins are overexpressed in E. coli, they often accumulate in the form of insoluble inclusion bodies, especially when the size of the fusion protein is over $50 \mathrm{kDa}$ (Marston 1987), which is close to the size of the GST-NS3 protein. Insolubility is associated with the presence of extensive and highly hydrophobic regions; as a result polypeptides tend to aggregate in inclusion bodies in order to minimize exposure of hydrophobic amino acid residues in aqueous solution (Volkin and Klibanov 1989). Modifications, such as thio-disulphide interchange and molecular conformational changes, also lead to exposure of hydrophobic amino acid residues and protein aggregation. Although insoluble proteins aggregate can be partially solubilized with non-ionic detergents, other bacterial proteins may contaminate the extract, inducing the production of other antibodies besides the ones against the protein of interest, which reduces specificity of the antiserum.

Antibodies against the RHBV ribonucleoprotein and the NS3 protein co-localized exclusively in the cytoplasm, no labeling was observed in vacuoles, chloroplasts, cell walls or viral inclusion bodies. The fact that NS3 and $\mathrm{N}$-protein were not detected in the inclusion bodies, agrees with the observation by Espinoza et al. (1993), that inclusion bodies are composed by a single kind of protein (noncapsid protein or NCP). It also rules out the function of the NS3 as a component of the inclusion bodies.

It is intriguing that both NS3 and the Nprotein co-localized in the same subcellular compartment. In nearly collapsed infected cells, there were fibers to which both proteins
(NS3 and N-protein) were found to associate. Those fibers were not coated uniformly; more gold-labeled N-protein-antibodies were found associated relative to NS3-antibodies, regardless of the gold particle size used. It is possible that antiserum produced against sucrose-gradient purified nucleocapsid protein is more antigenic than the NS3 protein used in this study, which was isolated under denaturing conditions, therefore conformational epitopes in native NS3 protein are not recognized efficiently by antibodies raised using denatured NS3 protein as antigen.

An alternative explanation is that fibrilar structures may be typical nucleocapsid, previously described for Tenuivirus, to which a few NS3 protein molecules associate. In fact, overall labeling with NS3-antibodies was less dense as compared with N-protein goldlabeled antibodies. However, low concentration of NS3-antibodies may indeed indicate that NS3 protein is expressed at lower levels in infected tissues as compared with the $\mathrm{N}$ protein. On the other hand, even at the same dilution, antibody titer may not comparable, which may also account for differences in the pattern of gold-labeling observed.

If N-protein and NS3 do interact, it is tempting to speculate that NS3 is the viral movement protein and associates with viral RNA or coat protein in RNPs. This would form a cell-to-cell movement complex, shuttling the viral N-protein to plasmodesmata, as in the model proposed by Lucas and Gilbertson (1994) and Citovsky and Zambrisky (1995).

However, there is still no evidence to assert that NS3 is indeed a movement protein. For instance, it is unknown whether NS3 has an RNA-binding domain or whether NS3 interacts directly with the $\mathrm{N}$ protein. Moreover, NS3 has not been found in plasmodesmata. Another question is whether co-localization of NS3 and N-protein in the same fibrilar structures is indicative of NS3 binding to viral RNA and formation of a single complex.

Further experiments should be carry out to assess the nature of NS3-N-protein interaction; for instance, gel retardation and band-shift 
assays may indicate whether NS3 has high affinity for RHBV RNA (Schoumacher et al. 1992, Thomas and Maule 1995). Subcellular localization of the NS3 may be determined by making a translational fusion with the jellyfish green fluorescent protein (GFP). Moreover, Nprotein and NS3 antibodies labeled with different fluorochrome may be studied by confocal microscopy and determine whether they colocalize in the same fibrilar structures. This study may be complemented with antibodies against tubulin and actin, since movement proteins have been found associated with cytoskeleton elements (McLean et al. 1995).

\section{ACKNOWLEGMENTS}

The authors appreciate Reynaldo Pereira for his collaboration in the in situ localization of the NS3 protein at the Electron Microscopy Unit of the University of Costa Rica. We wish to thank to R. Hull (John Innes Centre) and F. Albertazzi for their critical review of the manuscript. This study was supported by grants from The Rockefeller Foundation and the Universidad de Costa Rica.

\section{RESUMEN}

El gen que codifica por la proteína no estructural NS3 del virus de la hoja blanca de arroz (RHBV) se fusionó al extremo carboxilo del gen de la glutationa-S-transferasa y se expresó en la cepa JM83 de Escherichia coli. Se obtuvieron altas concentraciones de la proteína de fusion (GST-NS3) en forma insoluble. La proteína de fusión se fraccionó en geles de SDS-PAGE, se purificó por electroelución, y se utilizó para producir anticuerpos policlonales en conejo . El antisuero producido se absorbió con extractos crudos de E. coli. Extractos crudos de plantas de arroz sanas e infectadas con el RHBV se evaluaron por Western blots detectándose una banda de peso molecular similar al estimado para la proteína NS3 (23KDa) en las plantas infectadas con el virus. Los tejidos provenientes de plantas infectadas con el RHBV se analizaron por medio de microscopia inmunoelectrónica con oro colloidal marcado con anticuerpos contra la proteína NS3 y la nucleoproteína viral N. Se observó una acumulación in situ de la proteína NS3 en el citoplasma, pero no se detectó en los cuerpos de inclusion, vacuolas o cloroplastos. Se demostró que la proteína NS3 sigue el mismo patron de distribución que el de la nucleoproteína viral N del RHBV.

\section{REFERENCES}

Amann, E., J. Brosius \& M. Ptashne. 1983. Vectors bearing a hybrid trp-lac promoter useful for regulated expression of cloned genes in Escherichia coli. Gene 25: 167-178.

Citovsky, V. \& P. Zambrisky. 1995. Transport of nucleic acids through membrane channels: snaking through small holes. Ann. Rev. Microbiol. 47: 167-197.

de Miranda, J., M. Hernández, R. Hull \& A. Espinoza. 1994. Sequence analysis of rice hoja blanca virus RNA-3. J. Gen. Virol. 75: 2127-2132

de Miranda, J., R. Hull \& A.M. Espinoza. 1995. Sequence of the PV2 gene of rice hoja blanca tenuivirus RNA2. Virus Genes10: 205-209.

de Miranda, J., M. Muñoz, R. Wu \& A.M. Espinoza. 1996. Sequence of the Rice hoja blanca tenuivirus RNA-2. Virus Genes 12: 231: 237.

Dean P. 1991. Affinity chromatography: a practical approach. IRL. Oxford. $213 \mathrm{p}$.

Espinoza, A.M., M. Hernández, R. Pereira, B. Falk \& V. Medina. 1992. In situ immunogold labeling analysis of the Rice hoja blanca virus nucleoprotein and major non-capsid protein. Virology 191: 619-127.

Espinoza, A.M., R. Pereira, A., Macaya-Lizano, M. Hernández, M. Goulden \& C. Rivera. 1993. Comparative light and electron microscopic analyses of tenuivirus major non-capsid protein (NCP) inclusion bodies in infected plants and of the NCP in vitro. Virology 195: 156-166.

Huiet, L., V. Klaassen, J. Tsai \& B. Falk. 1991. Nucleotide sequence and RNA hybridization analyses reveal an ambisense coding strategy for maize stripe virus RNA3. Virology 182: 47-53.

Jennings, P. 1963. Estimating yield loss in rice caused by hoja blanca. Phytopathology 53: 492.

Kakutani, T., Y. Hayano, T. Hayashi \& Y. Minobe. 1991. Ambisense segment 3 of rice stripe virus: the first instance of a virus containing two ambisense segments. J. Gen. Virol. 72: 465-468.

Laemmli, U. 1970. Cleavage of structural proteins during the assembly of the head of the bacteriophage T4. Nature 227: 680-685.

Lucas, W. \& R. Gilbertson. 1994. Plasmodesmata in relation to viral movement within leaf tissues. Annu. Rev. Phytopathol. 32: 387-411.

Marston, F. 1987. The Purification of eukaryotic polypeptides expressed in Escherichia coli. In D.M. Glover (ed.). DNA cloning: a Practical approach. Volume III. IRL, Oxford. 
Nault, L. \& E. Ammar. 1989. Leafhopper and planthopper transmission of plant viruses. Annual Review of Entomology 34: 503-529.

Nguyen, M., B. Ramírez, R. Goldbach \& A. Haenni. 1997. Characterization of the in vitro activity of the RNAdependent RNA polymerase associated with the ribonucleoproteins of rice hoja blanca tenuivirus. J. Gen. Virol. 71: 2621-2627.

Ramírez, B., G. Macaya, L. Calvert \& A. Haenni. 1992. Rice hoja blanca virus genome. Characterization and expression in vitro. J. Gen. Virol. 73: 1457-1464.

Ramírez, B. \& A. Haenni. 1994. Molecular biology of tenuiviruses, a remarkable group of plant virases $\mathrm{J}$. Gen. Virol 75: 467-475.

Ramírez, B., I. Lozano, L. Constanino, A. Haenni \& L. Calvert. 1993. Complete nucleotide sequence and coding strategy of rice hoja blanca virus RNA-4. J. Gen. Virol. 74: 2463-2468.

Sambrook, J., E. Fritsch \& T. Maniatis. 1989. Molecular cloning: a laboratory manual, Cold Spring Harbor Laboratory, vol 3 pp. 17.3-17.42.

Schoumacher, F., C. Erny, A. Verna, T. Godefroy-Colburn \& C. Stussi-Garaud. 1992. Nucleic acid binding properties of the alfalfa mosaic virus protein produced in yeast. Virology 188: 896-899.
Smith, D. \& L. Corcoran. 1992. Expression and purification of glutathione-S-transferase fusio N-proteins, pp. 16.7.1-16.7.8. In F. Ausubel, R., Brent, R. Kingston, D. Moore, J. Seidman, J. Smith \& K. Struhl (eds). Current Protocols in Molecular Biology, vol II. 6th. John Wiley (ed.). New York.

Smith, D., K. Daver, P. Board, W. Tiu, E. García \& G. Mitchell. 1986. Mr 26000 antigen of Schistosoma japonicum recognized by resistant WEHI $129 / \mathrm{J}$ mice is a parasite Glutatione S-transferase. Proc. Natl. Acad. Sci., U.S.A. 38: 8703-8707.

Smith, D. \& K. Johnson. 1988. Single step purification of polypeptides expressed in Escherichia coli as fusions with Glutatione S-transferase. Gene 67: 31-40.

Thomas, C. \& A. Maule. 1995. Identification of the cauliflower mosaic virus movement protein RNA-binding domains. Virology 206: 1145-1149.

Toriyama S., M.Takahashi, Y. Sano \& T. Shimizu. 1994. Nucleotide sequence of RNA-1, the largest genomic segment of rice stripe virus, the prototype of the tenuiviruses. J. Gen. Virol. 75: 3569-3579.

Volkin, D. \& A. Klibanov. 1989. Minimizing protein inactivation, pp. 1-24. In T.E. Creighton (ed.). Protein function: a practical approach. IRL, Oxford University, Oxford, England. 